\title{
1 Applying Geospatial Technologies in Urban Environments
}

\author{
Ryan R. Jensen, Department of Geography, Geology \& Anthropology, Indiana \\ State University, Terre Haute, IN
}

Jay D. Gatrell, Department of Geography, Geology \& Anthropology, Indiana State University, Terre Haute, IN

Daniel D. McLean, Department of Recreation and Sport Management, Indiana State University, Terre Haute, IN

Cities have been around since the 3rd millennium B.C. and as long as they have existed, people have been drawn to them for what they offer. As recently as 1800, however, only 2 per cent of the world's population lived in urban areas. Today, with 6 billion people on earth, slightly less than one-half live in cities and towns; by 2007 one half of them will. In the century ahead, urban centres are expected to expand to sizes never before seen.

United Nations, Instanbul + 5, 2001, p. 1

\subsection{About this book}

As the epigraph suggest, cities are to become one of the chief policy concerns of the $21^{\text {st }}$ century. Moreover, cities are unique policy realms in that urbanization is an issue and process that resides at the nexus of human and physical systems and unites the research and policy interests of natural and social scientists alike. This is true as urbanization as a process unites often-disparate social and physical systems to create entirely new policy challenges such as environmental degradation, the development and maintenance of physical and social infrastructures, the challenge of expanding economic opportunities, designing effective service delivery regimes that promote the overall sustainability of urban areas, and assessing the policy outcomes. Consequently, researchers and policy makers are concerned with identifying and overcoming the full range of challenges associated with urban systems. Unfortunately, the ability of researchers and planners to assess and investigate complex urban systems has been somewhat frustrated by a lack effective and accessible research and decision making tools. Over the past fifteen years, remote sensing and geographic information systems (GIS) have been shown to provide an excellent way to investigate urban areas. However, the availability, "usability", and range of potential applications of these technologies had until recently been limited to a community of specialists and scientistist. Today remote 
sensing and GIS technologies provide an accessible and increasingly user friendly suite of data and data analyses that facilitate the integrated investigation of spatial information. Further, the ability of GIS to integrate tabular data with spatial data allows for detailed investigations with socioeconomic data. .

The purpose of this book was to assemble a collection of studies that investigate and develop alternate methodological approaches to understanding the urban environment. In particular, it seeks to bring together studies that use remote sensing technologies and geographic information systems to explore issues often ignored by the mainstream community of geo-technical specialists, such as environmental justice, the meaning of data, and the everyday lives of urban residents. This book is meant to bridge the gap between the geography / planning / public administration communities and others that use geospatial technologies. Urban resource professionals need new management practices, skills, and tools to address the new and changing urban environment, and research is needed to place the best scientific data into the hands of decision makers (Hermansen and Macie, 2002).

This book seeks to expand the current frame of reference of remote sensing and geographic information specialists to include an array of socio-economic and related planning issues. Using remotely sensed data, the project explores the efficacy and policy implications of new approaches toward analyzing data (i.e., homogeneity indices), integrates approaches from human geography (i.e., Expansion Method), and explores the utility of employing geo-technologies to further the politics of local growth and smart growth coalitions (i.e., green space). Indeed, this book seeks to build upon Longley's (2002) call for better urban geography by integrating these technologies into the urban environment.

\subsection{Chapters}

There are many ways to classify the 12 main chapters of this book including the techniques used, the context of the analysis, the data sets used, the spatial resolution or scale of the data and so on. Because of this breadth, it made classifying the chapters into specific groups very difficult. This book not only gives many research examples of geospatial technologies in urban areas, but it also provides the basics of these technologies in several introductory chapters. These chapters are meant to provide a foundation of these technologies to readers that are not as familiar with them. For example, those readers lacking a basic understanding of the principles of urban remote sensing should read chapter 2. Those seeking to understand more of the Casetti expansion method and its role in this book and in spatial data processing should read chapter 5. Chapter 3 describes policy implications of remote sensing through a case study. Many chapters demonstrate the potential role of geospatial technologies in examining and solving urban problems. Specifically, two chapters examine urban quality of life and environmental justice (Chapters $7 \& 8$ ). Another chapter details how local community leaders perceive the 
costs and benefits of the urban forest to their community (Chapter 9) and how a healthy urban forest can actually spur economic development (Chapter 11), while another chapter details the economic impact of urban forestry on summertime electrical energy usage (Chapter 6). Chapter 10 reviews much of the remote sensing urban heat island literature and provides an urban heat island case study. Those readers seeking an example of how to provide spatial data to the public should read chapter 4 . Chapter 12 describes how remote sensing can be used to estimate urban sprawl, and chapter 13 details the links between satellite and census data.

Table 1. Summary of substantive chapters in this book

\begin{tabular}{|c|c|c|}
\hline & Author(s) & Subject \\
\hline 2 & J. Jensen et al. & Urban remote sensing \\
\hline 3 & Lawrence et al. & $\begin{array}{l}\text { Policy implications of remote sensing detection of } \\
\text { an urban wetland }\end{array}$ \\
\hline 4 & Morgan et al. & $\begin{array}{l}\text { Making spatial and tabular data available to the } \\
\text { public - the case of Internet tax mapping }\end{array}$ \\
\hline 5 & Gatrell & $\begin{array}{l}\text { Assessing socio-spatial interactions with the ex- } \\
\text { pansion method }\end{array}$ \\
\hline 6 & R. Jensen et al. & $\begin{array}{l}\text { Relationship between urban leaf area and energy } \\
\text { consumption }\end{array}$ \\
\hline 7 & R. Jensen et al. & $\begin{array}{l}\text { Using remote sensing technologies to study urban } \\
\text { environmental justice }\end{array}$ \\
\hline 8 & $\begin{array}{l}\text { R. Jensen and Ga- } \\
\text { trell }\end{array}$ & Using texture to assess urban quality of life \\
\hline 9 & McLean et al. & $\begin{array}{l}\text { Local government leaders perceptions of the urban } \\
\text { forest }\end{array}$ \\
\hline 10 & Weng and Larson & Remote sensing of urban heat islands \\
\hline 11 & Gatrell and Jensen & $\begin{array}{l}\text { Remote sensing and urban assessment - using re- } \\
\text { mote sensing and urban forestry to compete for lo- } \\
\text { cal investment }\end{array}$ \\
\hline 12 & Hanham and Spiker & Urban sprawl detection using remote sensing \\
\hline 13 & $\begin{array}{l}\text { Muller and } \\
\text { Gossette }\end{array}$ & $\begin{array}{l}\text { The relationship between urban structural variables } \\
\text { and socioeconomic conditions }\end{array}$ \\
\hline
\end{tabular}

The authors and editors hope that this book will be used by planners, landscape architects, urban foresters, GIS and remote sensing specialists, and many others to improve quality of life in the urban environment. People will continue to migrate to urban areas. Our ability to examine and mitigate the potential negative impacts of this migration is very important today and will be even more important tomorrow. As such, this book and the studies contained within it should be used as a point of reference of sorts for those who might imagine and re-imagine the range of potential geo-technical applications to assist urban decision making and promote the overall sustainability of social and physical systems. 


\section{References}

Hermansen, L.A. and E. A. Macie. 2002. "Introduction." In Human Influences on Forest Ecosystems. United States Department of Agriculture, Forest Service General Technical Report SRS-55

Longley, P.A. 2002. "Geographical information systems: will developments in urban remote sensing and GIS lead to 'better' urban geography?' Progress in Human Geography 26:231-239.

United Nations Centre for Human Settlements (HABITAT). 2001. BROCHURE: Istanbul + 5: The United Nations Special Session of the General Assembly for an Overall Review and Appraisal of the Implementation of the Habitat Agenda. New York: United Nations, Department of Public Information, 8 pages with figures. 